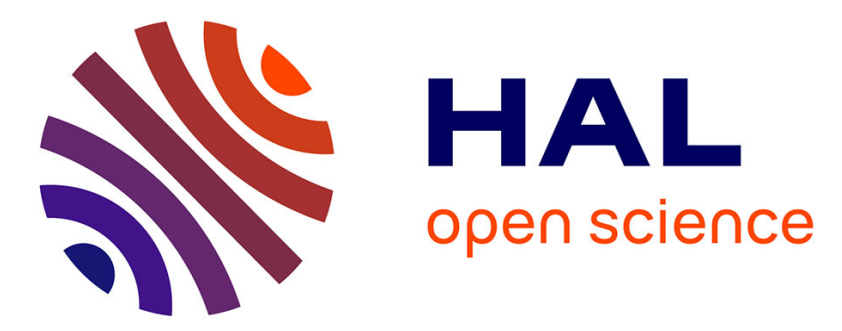

\title{
Trace metal enrichments in water of the Okavango Delta (Botswana): hydrological consequences
}

Olivier Dauteuil, Marc Jolivet, Aline Dia, M. Murray-hudson, K. Makati, L. Barrier, Martine Bouhnik-Le Coz, A. Audran, A. Radenac

\section{- To cite this version:}

Olivier Dauteuil, Marc Jolivet, Aline Dia, M. Murray-hudson, K. Makati, et al.. Trace metal enrichments in water of the Okavango Delta (Botswana): hydrological consequences. Geochemistry, Geophysics, Geosystems, 2021, 2 (5), pp.e2021GC009856. 10.1029/2021GC009856 . insu-03220219v2

\section{HAL Id: insu-03220219 \\ https://hal-insu.archives-ouvertes.fr/insu-03220219v2}

Submitted on 17 May 2021

HAL is a multi-disciplinary open access archive for the deposit and dissemination of scientific research documents, whether they are published or not. The documents may come from teaching and research institutions in France or abroad, or from public or private research centers.
L'archive ouverte pluridisciplinaire HAL, est destinée au dépôt et à la diffusion de documents scientifiques de niveau recherche, publiés ou non, émanant des établissements d'enseignement et de recherche français ou étrangers, des laboratoires publics ou privés. 


\section{Geochemistry, Geophysics, Geosystems}

\author{
RESEARCH ARTICLE \\ 10.1029/2021GC009856 \\ Key Points: \\ - Hydrological data, Rare Earth \\ Elements (REE) patterns and \\ geochemical data reveal different \\ sources of water located in two \\ independent aquifers \\ - Two different types of water with \\ low element concentrations for \\ fresh water in an unconfined aquifer \\ versus highly enriched chemical \\ concentrations in a confined aquifer \\ at depth \\ - Alkaline groundwater inside island \\ displaying REE patterns exhibiting \\ enrichment from LREE to HREE
}

Supporting Information: Supporting Information may be found in the online version of this article.

Correspondence to:

O. Dauteuil,

olivier.dauteuil@univ-rennes1.fr

Citation:

Dauteuil, O., Jolivet, M., Dia, A., Murray-Hudson, M., Makati, K., Barrier, L., et al. (2021). Trace metal enrichments in water of the Okavango Delta (Botswana): Hydrological consequences.

Geochemistry, Geophysics, Geosystems, 22, e2021GC009856. https://doi. org/10.1029/2021GC009856

Received 21 APR 2021 Accepted 3 MAY 2021
(C) 2021. American Geophysical Union. All Rights Reserved.

\section{Trace Metal Enrichments in Water of the Okavango Delta (Botswana): Hydrological Consequences}

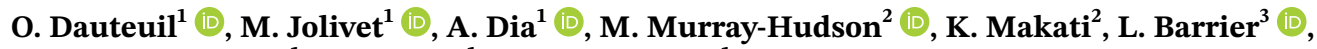 \\ M. Bouhnik Le Coz ${ }^{1}$, A. Audran ${ }^{1}$, and A. Radenac ${ }^{1}$ \\ ${ }^{1}$ University of Rennes, CNRS, Géosciences Rennes-UMR 6118, Rennes, France, ${ }^{2}$ Okavango Research Institute, \\ University of Botswana, Maun, Botswana, ${ }^{3}$ Laboratoire de Tectonique et Mécanique, IPGP, University of Paris, Paris, \\ France
}

Abstract The Okavango Delta in northern Botswana is an endorheic ecosystem formed by 150,000 islands surrounded by a flood plain. The vegetation of these islands displays an external tree ring enclosing a barren interior domain with evaporitic deposits. We sampled the groundwater into piezometers across an island at the southwest of the Delta, and drilled sediments. The geochemical analysis of the water exhibits two different compositions: a fresh water in the floodplain and a saline water in the interior part. These inner samples display enrichments in heavy metals, metalloids and critical metals such as, Rare Earth Elements (REE). The latest show a continuous enrichment from LREE to HREE and positive Ce and Eu anomalies, associated to alkaline pH. Overall, the two types of displayed REE patterns fingerprint two different water sources. The geochemistry of sediments indicates the same composition whatever the sample location and no traces of evaporitic deposits was found. The variations in the water table depth in the piezometers shows different hydrological behaviors in between the floodplain and the barren zone which does not follow the flood cycle. Thus, we document two different aquifers with independent hydrological behaviors: a surface fresh-water aquifer in the floodplain connected to the channels, and a saline confined aquifer below the islands. The contrasted geochemical composition of the waters explains the distribution of the vegetation which survives through access to fresh water. The hydrological architecture of this island in the southwestern Delta differs from other islands, highlighting the hydrological complexity of the Okavango Delta.

Plain Language Summary Endorheic basins are hotspots for biodiversity and human activities. The Okavango Delta in northern Botswana is one of the largest wetlands in Africa, and forms a huge oasis in the arid Kalahari Desert. The water flowing from Angola reaches the mega-alluvial fan confined in between two fault zones, before being absorbed by evaporation and evapotranspiration. The 150,000 islands scattering the wetland are surrounded by an annually flooded alluvial plain. The depth of the water table in the floodplain follows the water level variations in the channels; whereas it remains deeper and nearly constant in the interior part of the island. The chemical analysis of the water samples recovered in piezometers reveals that the deep saline water contains high concentrations of trace elements, whereas the water sampled in the floodplain is fresh with low concentrations in trace element. The chemical quality of the waters and the non-correlated variations in the water tables through time indicate the occurrence of two independent aquifers: one on the surface with fresh water and a second one at a table depth of 2-3 m with more saline water. This model proposed for the southwestern part of the Delta differs from the hydrochemical system established for islands in the eastern region, highlighting the hydrological complexity of the endoreic ecosystem of Okavango.

\section{Introduction}

Endorheic fluvial megafans constitute major hotspots for biodiversity and are of major economic interest, especially since endorheic basins are mainly located in arid to semi-arid regions (Yapiyev et al., 2017). The large-scale dynamics of these megafans is driven both by authigenic processes (precipitation, temperature, solid and dissolved element transport, tectonic deformation, mantle dynamics) and authigenic ones (channel dynamics, biological processes). The most important parameter is the water that sustains these fragile geo-ecosystems, especially in an arid to semi-arid climate context: a slight climatic change modifying the water supply and/or the evaporation rates will unbalance the system leading to geological and ecological 
modifications (Habeck-Fardy \& Nanson, 2014). In addition to these natural causes of changes, the anthropic activities can drastically modify this fragile equilibrium (Markofsky et al., 2017), by changing the amount of inflow (pumping, dams), and/or changing its chemical composition (agriculture, industry, city). Inside these megafans, biological activity and evaporation are the most important process that controls on water chemistry in such a confined context (Atekwana et al., 2016; Bauer et al., 2004; Frondini et al., 2019; Hammer, 1986; Mahamat Nour et al., 2020; Ramberg \& Wolski, 2008; Tweed et al., 2011; Wang et al., 2018). The Okavango Delta in Botswana is poorly disturbed by anthropic activities both in the wide watershed and inland: also, it offers a good opportunity to constrain the natural process driving the water quality within an endorheic megafan.

\section{Study Site Background}

The Okavango Delta (Figure 1), one of the three well-known megafans in Africa (McCarthy, 1993), is a $170 \mathrm{~km}$-long and $190 \mathrm{~km}$-wide endorheic alluvial fan, inscribed in the UNESCO world heritage list. Water inflow is provided through the annual flooding of the Okavango River draining the Angola mountains watersheds, and complemented by approximately $450 \mathrm{~mm} \mathrm{yr}^{-1}$ of local rainfall (Kenabatho et al., 2012; Wolski et al., 2012). The water flow is landlocked by a set of NE-SW faults forming a graben in response to the Plio-Pleistocene southwestward propagation of the East African Rift System (Kinabo et al., 2007; Moore \& Larkin, 2001; Pastier et al., 2017). The late Neogene to Quaternary regional geomorphic evolution is characterized by two main periods (Moore et al., 2012): the Middle to Late Pleistocene corresponding to a succession of mega-paleolakes, the size of which decreased through time consecutive to climate changes and the geodynamic modification of the drainage system. The Late Pleistocene to Holocene characterized by the formation of a wide alluvial fan supporting the present-day Okavango Delta and the near complete drying of the remaining lakes. The Late Quaternary dynamics of this endorheic system located in a semi-arid context is controlled by: (a) the tectonic extension in the Okavango graben, (b) the supply of fluvial, lacustrine and aeolian clastic material, and (c) the water budget (Figure 1).

The water budget of the Delta is balanced through the flood inflow, local rainfall, evaporation, transpiration, possible storage in aquifers (Ahmed et al., 2014; Ramillien et al., 2008), and outflow (Andersson et al., 2003; Bauer et al., 2004; McCarthy, 2013). Evaporation and transpiration consume up to $98 \%$ of the water supply, and the remaining $2 \%$ are mainly discharged outside of the fan system, solely via the Boteti River. The Delta is a swamp in which over 150,000 islands emerge, surrounded by floodplains that are inundated every year during 4-5 months (Gumbricht et al., 2004; Wolski \& Murray-Hudson, 2008; Wolski et al., 2006). Some of these islands display a singular topographic and vegetation pattern (Figure 3): a flat, nearly barren inner domain is surrounded by a more or less continuous ring of trees generally growing on a ridge 2-3 m higher than the inner domain and the surrounding floodplain covered by thick grass (Bauer-Gottwein et al., 2007; Milzow et al., 2009). The tree ring is mainly composed of acacias, lead-wood, and ivory palm trees; some of these species grow in alkaline and sandy soils (Barboni et al., 2019; Ringrose et al., 2007; Tsheboeng et al., 2014). The lack of vegetation in the inner domain is generally attributed to the precipitation of salt onto the surface and to the chemical composition of the groundwater characterized by high $\mathrm{pH}(>8)$ and high concentrations of dissolved anions, cations and toxic metal elements (Bauer-Gottwein et al., 2007; Huntsman-Mapila et al., 2006; Mladenov et al., 2014; Mmualefe \& Torto, 2011). These studies also pointed out that the high salinity of the groundwater below the islands is in sharp contrast with the composition of the fresh water flowing in the channels.

The chemical composition of the saline water is commonly explained through an evapotranspiration-based model (Akoko et al., 2013; Bauer et al., 2004; Ellery \& McCarthy, 1994; McCarthy, 2013; Milzow et al., 2009; Ramberg \& Wolski, 2008). During high flood periods, the water migrates underground from the channels and floodplain toward the central part of the islands, crossing the tree ring where it is largely taken up by the tree roots. Evapotranspiration in the tree ring and capillary evaporation in the barren zone concentrate the dissolved solids in the residual water forming high-density sinking saline water (Bauer-Gottwein et al., 2007; McCarthy, 2006, McCarthy, 2013). The progressive increase in the water salinity reaches the solubility limit of some precipitating minerals (carbonates and silica). These mineral precipitations generate swelling in the soil and slightly increase the elevation of the island topography (Ellery \& McCarthy, 1994; McCarthy, 2006; McCarthy et al., 1986, 1988; Milzow et al., 2009). This horizontal flow associated to a 


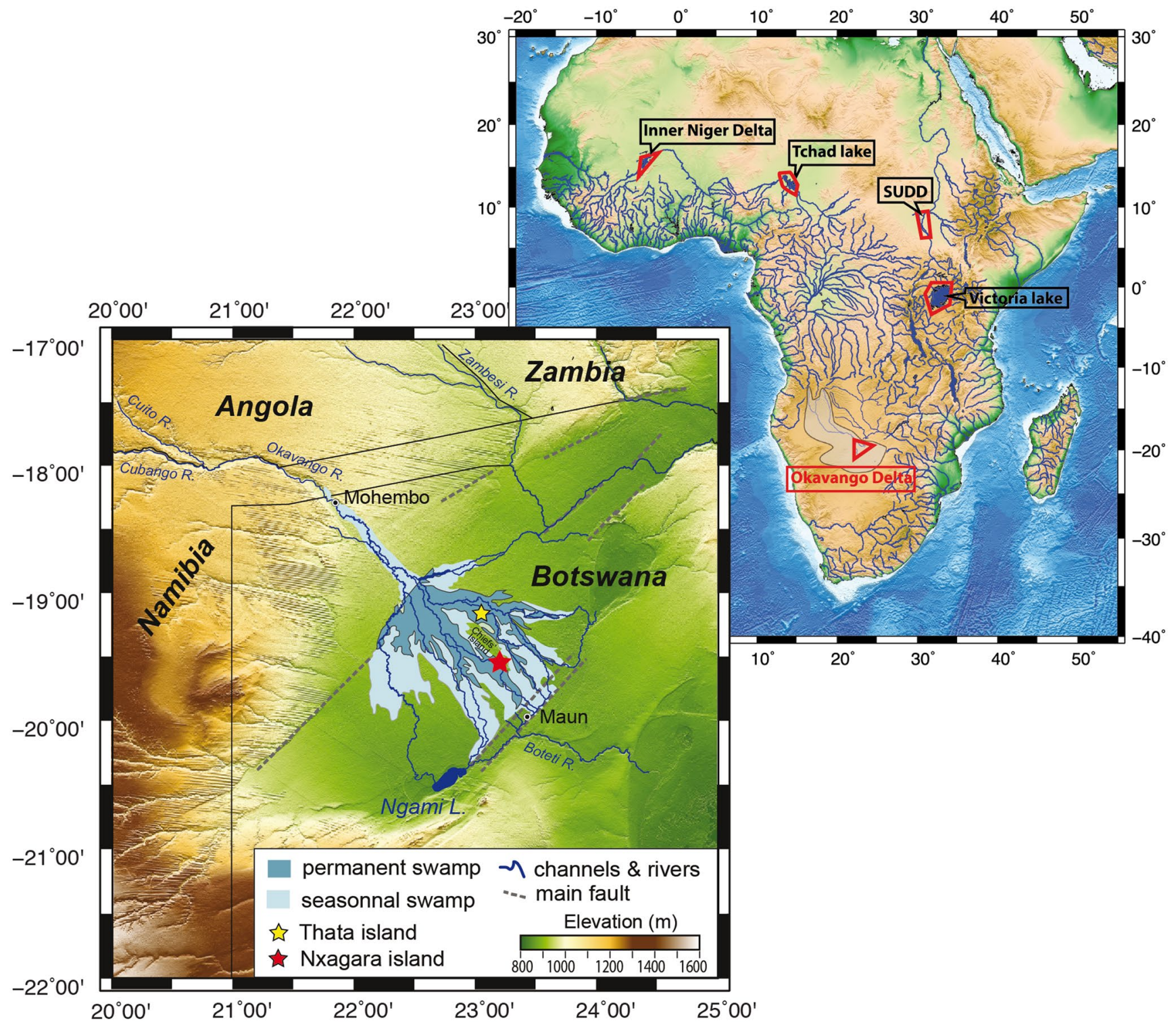

Figure 1. Location map of the study area. (a) The main inner deltas and alluvial fans in Africa. The red triangle shows the location of the study area: the Okavango Delta. The light gray color shows the watershed of the Okavango drainage system in which large amount of water comes from the Angola mountains. (b) Topographic map of the Okavango Delta with the extent of the permanent (dark blue) and seasonal swamps (light blue). The red star shows the location of Naxaraga Island, the island investigated in this study.

downward flow suggests a convective water circulation driven by density and chemical gradients from the channel to the inner part of the island (Figure 3). However, a convective cell should impose a horizontal flow at depth and possibly an upward flow outside the island to compensate for the downward flow, which is not observed until now. If this upward flow does not exist, a deep storage of saline water must happen. The initial model describing the formation of a saline water drop in the center of the Okavango islands was established based on the description of islands along the Nqoga and Maunachira rivers that flow into permanent swamps in the eastern part of the Delta (Thata Island, along the Ngoga River has become the key reference) (Figure 1). This model has then been applied to all of the other islands with saline underground water and the typical concentric vegetation pattern. In this study, we present an integrative analysis of hydrological measurements and geochemical analyses from surface water, groundwater and sediments sampled in the Nxaraga Island located at the southwestern part of the Delta. 


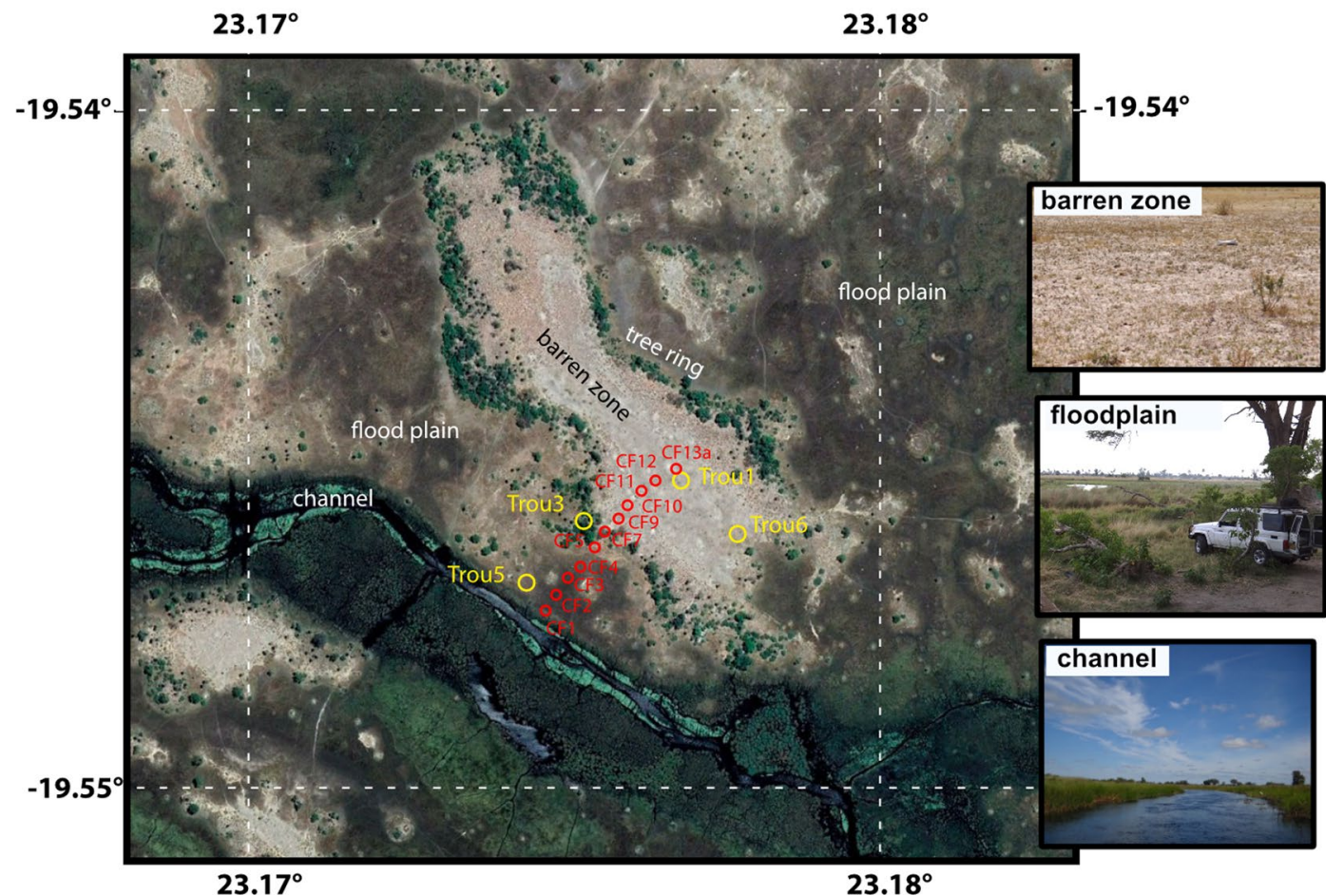

$23.17^{\circ}$

FLOOD

PLAIN

\begin{abstract}
TOPOGRAPHIC RIDGE WITH TREE RING
\end{abstract}

BARREN ZONE

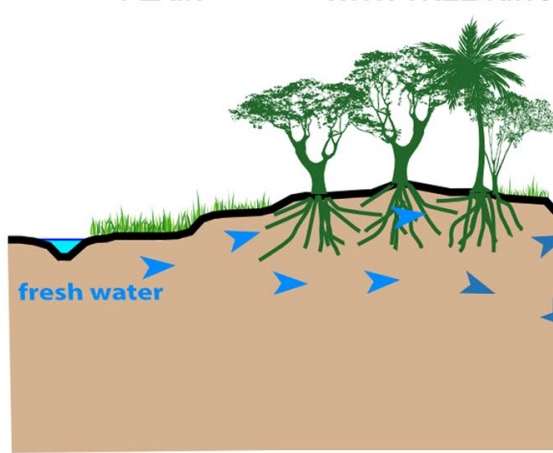

$23.18^{\circ}$

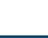

(n)




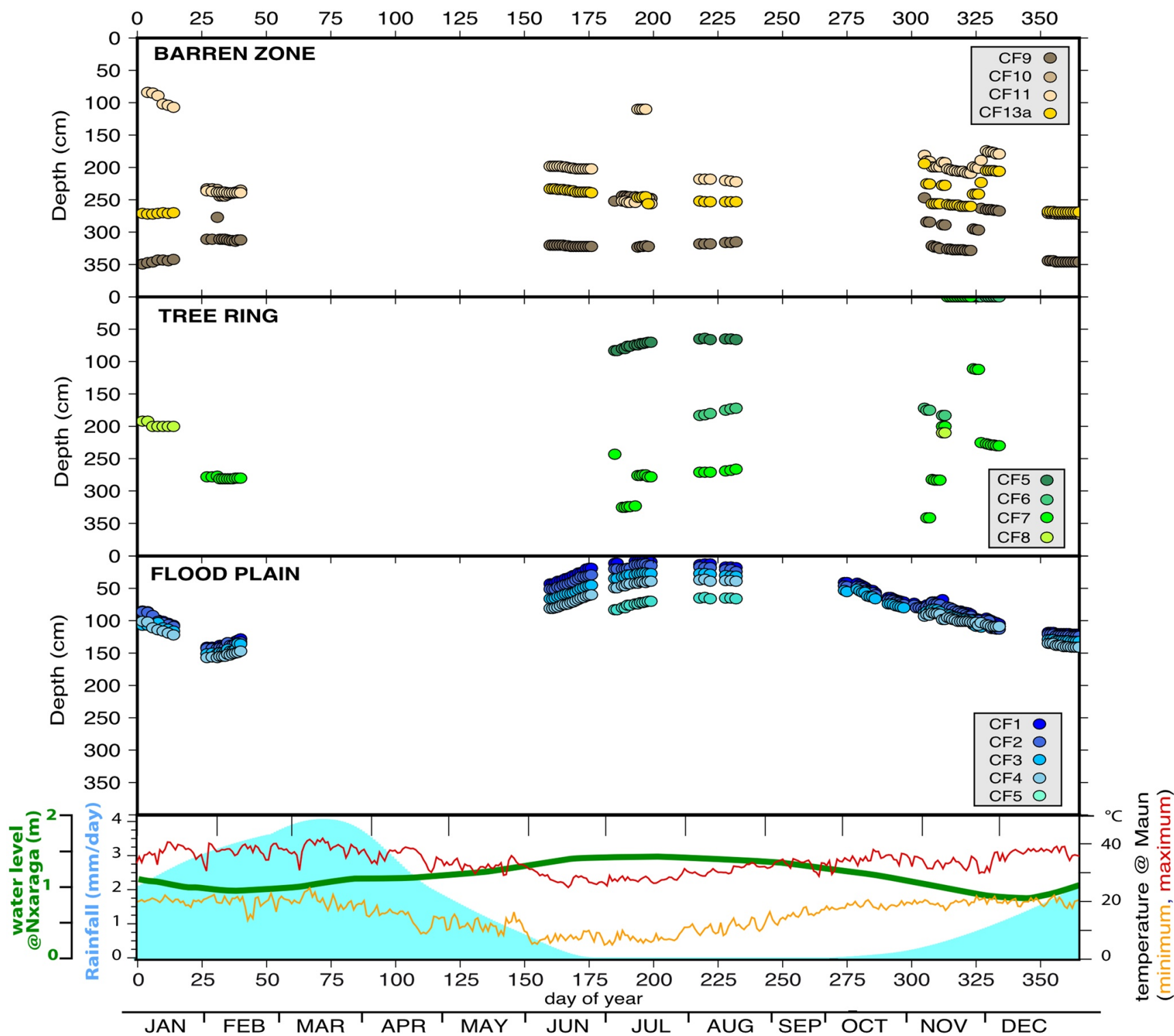

Figure 3. Time variations of water table recorded in the piezometers located in a transect close the channel (CF1) to the inner barren zone (CF13a). CF1 to CF5 are located in the floodplain (lower middle plot), whereas CF6 to CF8 are in the tree ring (upper middle plot), and CF9 to CF13a are in the barren zone (upper plot). Data are recorded from November 2017 to February 2019; each date is converted into the day number of each year. In the lowest plot, the orange and red lines show the minimum and maximum temperatures in ${ }^{\circ} \mathrm{C}$, the dark blue line the water level in Boro channel close to Nxaraga island in meters, and the light blue area the rainfall in $\mathrm{mm} /$ day.

and $60-\mathrm{m}$ - to 110-m-wide) is nearly devoid of vegetation except for patches of short grass and a few succulent plants (hereafter referred to as the barren domain). The transition area between the inner domain and the tree ring is characterized by a zone covered with dry bushes. Outward from the tree ring, the floodplain is characterized by dense high grass, and reeds cover the banks of the Boro River channel. The sediment in both the floodplain and the island is composed of fine to medium grained, rounded to sub-rounded quartzrich sand of mixed fluvial and aeolian origin (Huntsman-Mapila et al., 2006; Huntsman-Mapila, Ringrose, et al., 2006; McCarthy et al., 2012). A series of piezometers set on a line crossing the island from the channel to the middle of the barren zone were used to collect water samples and measure the water table depth (Figure 2). 


\subsection{Hydrological Data}

The level of the water table was recorded in the piezometers from 1 October 2017-14 January 2019, that is, longer than one complete annual hydrological cycle. The time variations in each piezometer were reported relative to one year. Then, a simple daily average was estimated and the minimum and maximum values are indicated as a range. The data were irregularly recorded, depending on the visits of the site only driven by the accessibility.

\subsection{Water Chemical Analyses}

The water samples were collected in the Boro channel close to Nxaraga Island, and in the piezometers (Figure 2). The design of the piezometers allows a sampling of the water at depth up to $4 \mathrm{~m}$ below the surface. This sampling was done during the dry season in October 2018. The $\mathrm{pH}$, conductivity and temperature were measured in situ prior to sampling (Table S1). A large set of chemical analyses was performed including major cation and anion, dissolved organic and inorganic carbon, and trace element concentrations (Tables S2 and S3). The data are available in OpenScienceFramework site. Each collected water sample was divided into two fractions: (a) a first one of filtered sample (by using $0.2 \mu \mathrm{m}$ cut-off acetate cellulose filters) was kept for dissolved organic and inorganic carbon as well as anion concentration measurements whereas (b) a second aliquot of filtered and acidified sample was recovered for major and trace cation concentration measurements. The different analytical methods used are described as follows.

\subsubsection{Dissolved Organic and Inorganic Carbon Concentration Analysis}

Dissolved Organic Carbon (DOC) and Dissolved Inorganic Carbon (DIC) concentrations were determined using a Total Carbon Analyzer (Shimadzu TOC-VCSH) with a standard solution of potassium hydrogen phthalate (Sigma Aldrich). The uncertainty of the measurement was below 5\% and checked for each analysis.

\subsubsection{Major and Trace Anion Concentration Analysis}

$\mathrm{Cl}^{-}, \mathrm{F}^{-}, \mathrm{NO}_{3}^{-}, \mathrm{NO}_{2}^{-}, \mathrm{SO}_{4}^{2-}$, and $\mathrm{PO}_{4}^{3-}$ concentrations were analyzed by ion chromatography (Dionex, model ICS-5000+ EG), with a precision of $\pm 4 \%$.

\subsubsection{Major and Trace Cation Concentration Analysis}

Field-filtered samples were directly acidified (in laboratory distilled nitric acid-pre-cleaned bottles) with distilled nitric acid $(\mathrm{HNO} 3 ; 14.6 \mathrm{~N})$ at $2 \% \mathrm{v} / \mathrm{v}$ prior to ICP-MS analysis. The major and trace elementincluding REE-concentrations, were determined by Quadruple ICP-MS using an Agilent Technologies 7700x. The analyses were performed using a conventional external calibration procedure with seven external standard multi-element solutions (from Inorganic Venture, USA). A mixed solution of rhodium-rhenium was used as an internal standard to correct the instrumental drift and potential matrix effects. Calibration curves and accuracy controls were performed using the international river water geostandard (SLR-6, National Research Council of Canada) as a reference material for trace elements with a large compositional range. The instrumental error on the REE and other cations analysis was below 5\%.

\subsection{Sediment Analyses}

The surface of the barren zone in Nxagara island (top picture on Figure 2) does not display evaporitic deposits as on Thata island. To confirm this observation, four boreholes (Figure 2) were drilled with an auger up to a depth of $4 \mathrm{~m}$ : two in the barren zone (Trou1, Trou6), one in the tree ring (Trou3), and one flood plain (Trou5). There are located close the piezometers, except for the Trou6 located at southeast of the barren zone. The geochemistry of the sediments sampled in the first meter of each boreholes were determined by the SARM center in Nancy. Cations, anions, trace elements, REE were determined: but we present only cation results in this study to evaluate the presence of evaporitic phases in the sediments (Table S4). Data are available on OpenScienceFramework site. 


\section{Results}

\subsection{Water Table Dynamics}

The evolution in the water table depth (Figure 3) provides pertinent information about the hydrological connection in between the different domains of the island. In the floodplain, the water table ranges from the surface during the flooding periods (from June to September), down to $1.5 \mathrm{~m}$ below the ground surface during the dry seasons (from December to March). This evolution is similar to the water level in the channel. The amplitude of the water table variations is the same in all the piezometers located in the flood plain without any significant offset in time, indicating a good hydrological connectivity in between the channel and the flood plain. This result is consistent with a relatively high permeability of the sand in the flood plain. The water table in the barren zone ranges from 2 to $3.5 \mathrm{~m}$ below the ground surface depending on the piezometer; each one displaying a limited range of annual variations up to $0.5 \mathrm{~m}$. The water table below the tree ring displays very irregular variations of less than $4.5 \mathrm{~m}$ with a lot of gaps in the records due to a lack of water inside the piezometers, indicating that the water table is lower than the bottom of the piezometers, that is, deeper than $4 \mathrm{~m}$ relative the ground surface.

In the Delta, the water supply comes from the local rainfall and the flood. Figure 3 displays the climatic parameters: temperatures, precipitations and water level in the Boro channel near Nxaraga, as a proxy of the flooding. None of the three domains shows a correlation in between the water level and the rainfall which is maximum from February to April, indicating that the rainfall does not significantly contribute to the amount of the groundwater. The rainfall period happens during the hot period of the year that increases the evaporation and favors the vegetation growth. Thus, the water is quickly removed from the geosystem during this period and cannot contribute significantly to the groundwater. The water table in the flood plain follows the flooding variation, while the tree ring and the barren zone do not seem to be very sensitive to the climate variations, indicating that another process contributes to the groundwater.

\subsection{Water Chemistry}

The water chemistry evidences two contrasted domains: the flood plain and the barren zone separated by the tree ring (Figure 6). The chemical composition of the water in the channel and floodplain corresponds to a fresh water, with lower circumneutral $\mathrm{pH}$ values, low conductivities (some tens of $\mu \mathrm{S}$ ), and temperature around $22^{\circ} \mathrm{C}$. The DOC, DIC, major, and trace elements display very low contents. In the barren zone, the chemical landscape of the water is completely different: the $\mathrm{pH}$ reaches high values, up to 9.2, the conductivity is three orders of magnitude higher, reaching some tens of $\mathrm{mS}$, and all the chemical elements show much higher contents. In particular, these samples display enrichments in heavy metals, critical metals and metalloids: for example, Cr: x60, Pb: x10, V: x750, U: x40, Th: x6, and As: x3000, relative to the fresh water recovered in the channel.

The water samples with the highest conductivities and $\mathrm{pH}$ also display the highest DOC and DIC concentrations. The strong relationship linking high DIC values and high $\mathrm{pH}$ in the island samples is characteristic of alkaline $\mathrm{CO}_{3}^{2-}$ and $\mathrm{HCO}_{3}^{-}$-rich waters resulting from interactions in between water and carbonate-rocks. The marked DOC enrichment is mostly related to the microbial degradation of plant-derived organic matter and/or hydrological condition variations favoring DOC release (Cawley et al., 2012; Mladenov et al., 2007). Significant enrichments in $\mathrm{Cl}^{-}, \mathrm{SO}_{4}^{2-}$, and $\mathrm{NO}_{3}^{-}$as well as major cations are also evidenced in the same group of samples taken in the inner area of the island suggesting that biological processes occur.

However, the most unexpected results are found in the fingerprints of the trace elements found in the deep water of the barren zone (Figure 4). Upper Continental Crust-normalized REE patterns display two markedly contrasting shapes (Table S2, Figure 5). Circumneutral $\mathrm{pH}$ waters exhibit relatively flat patterns with slight middle-REE enrichment, commonly observed in rivers draining metamorphic and igneous terranes (Bayon et al., 2015; Nance \& Taylor, 1976). By contrast, alkaline waters display the highest total REE concentrations, a continuous enrichment throughout the whole series from LREE to HREE and positive Ce and $\mathrm{Eu}$ anomalies (Figure 5). These two contrasted patterns represent two end-members of water composition, in coherence with the other chemical data. 

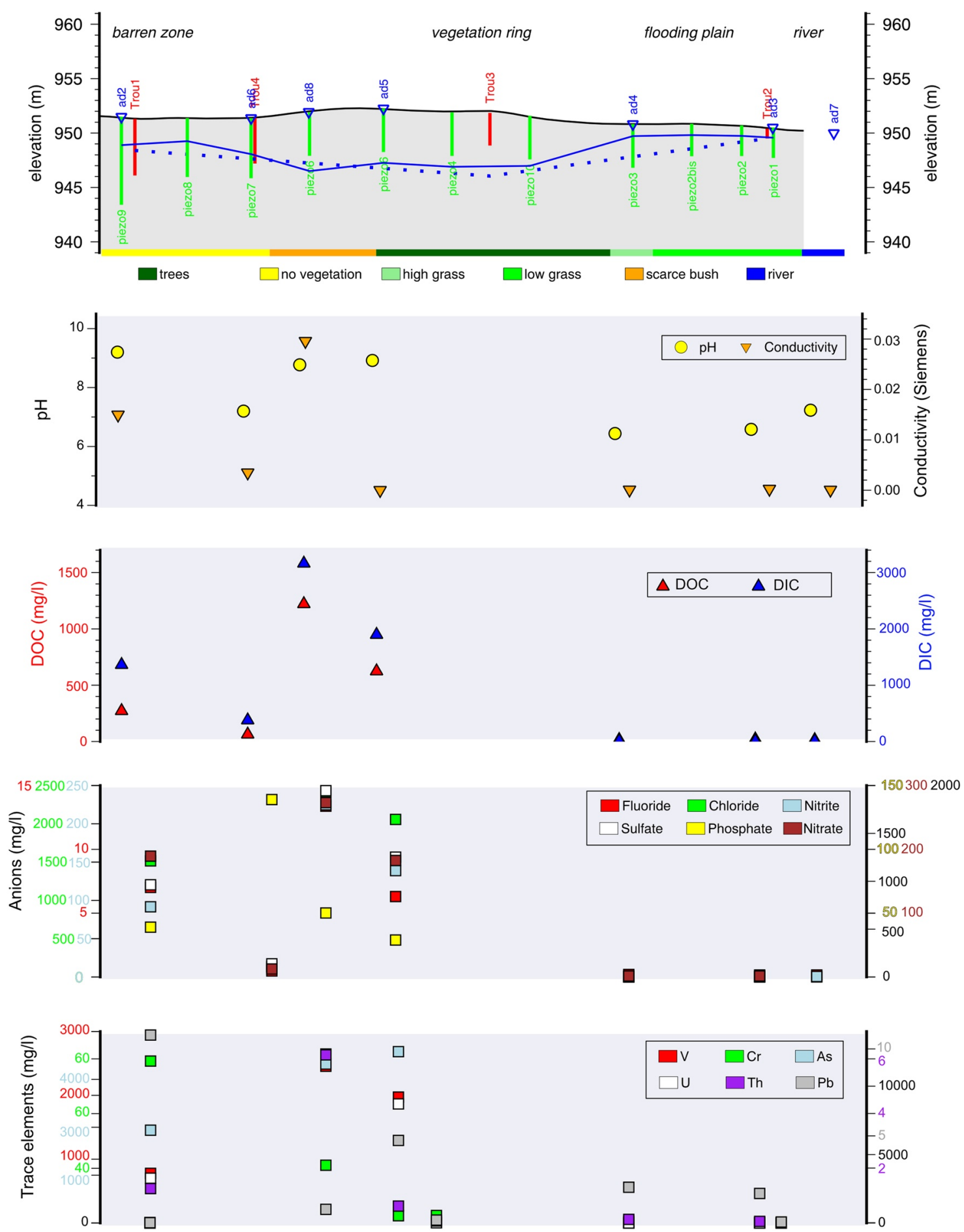

Figure 4. Geochemistry of the water sampled in the piezometers: the upper graph corresponds to the topographic profile with the piezometer and sample locations, whereas the upper middle graph displays the $\mathrm{pH}$ and conductivity, the middle graph shows the Dissolved Organic Carbon (DOC) and Dissolved Inorganic Carbon (DIC) concentrations, the middle lower graph gives selected trace element profiles, whereas the lower graph provides the cation and anion concentrations, respectively. 
a) WSW-ESE section of the Nxagara island
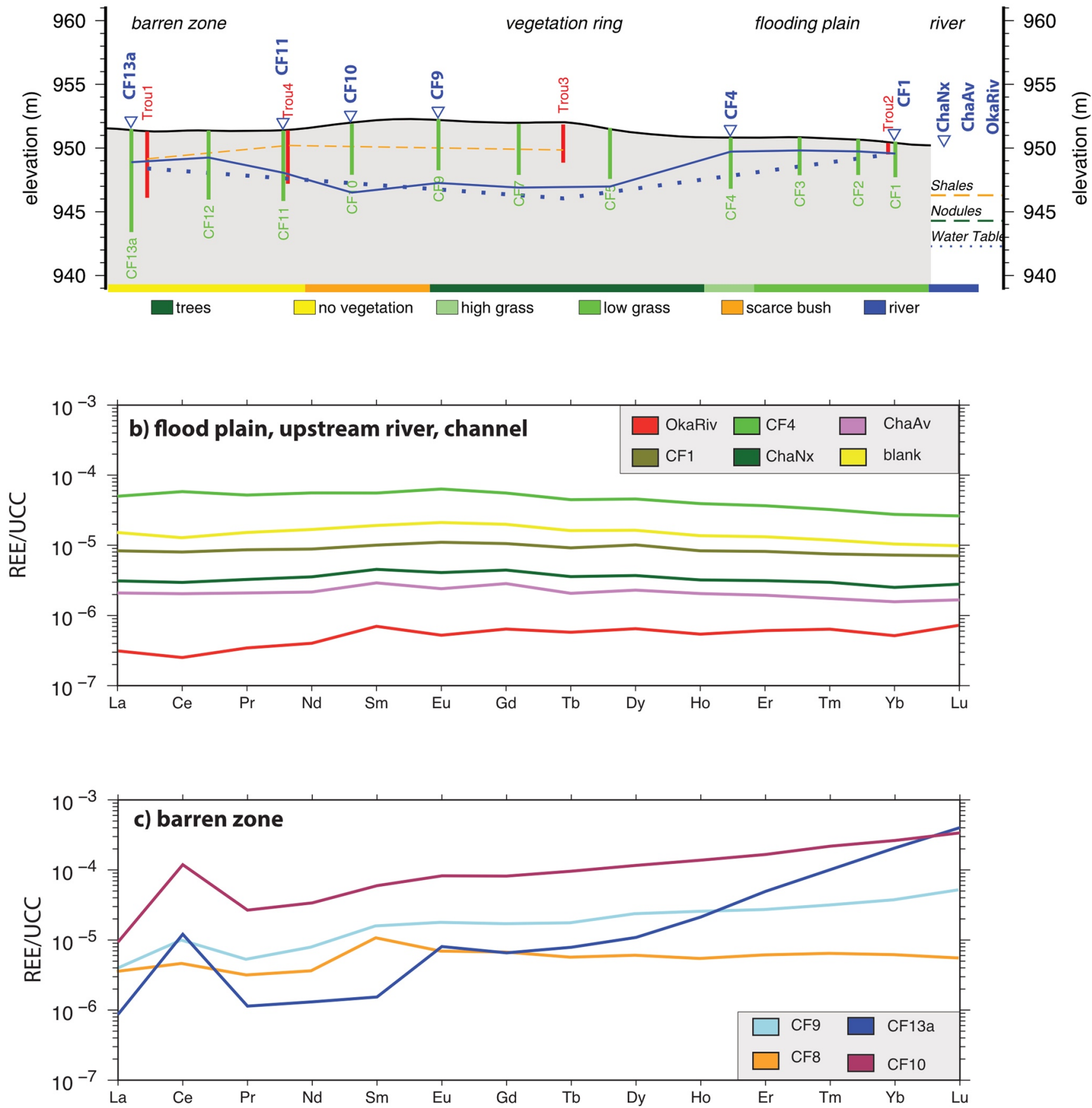

Figure 5. Rare Earth Elements patterns of the water sampled in the piezometers: (a) section of the Nxaraga Island with the location of the piezometers and the vegetation distribution (the blue color shows the location of the water table, the orange line indicates the clay level and the dashed green line represents the nodule level), (b) in the floodplain, upstream in the river and channel, and (c) in the barren zone.

The chemical analyses highlight two aquifers with highly contrasted compositions. The transition in between them occurs at the tree ring, over a distance wide of $50 \mathrm{~m}$ approximately. No intermediate values were observed that could indicate a progressive transition in between the two domains, whichever the chemical analysis regarded. Thus, the transition in between the two types of water is very sharp. 


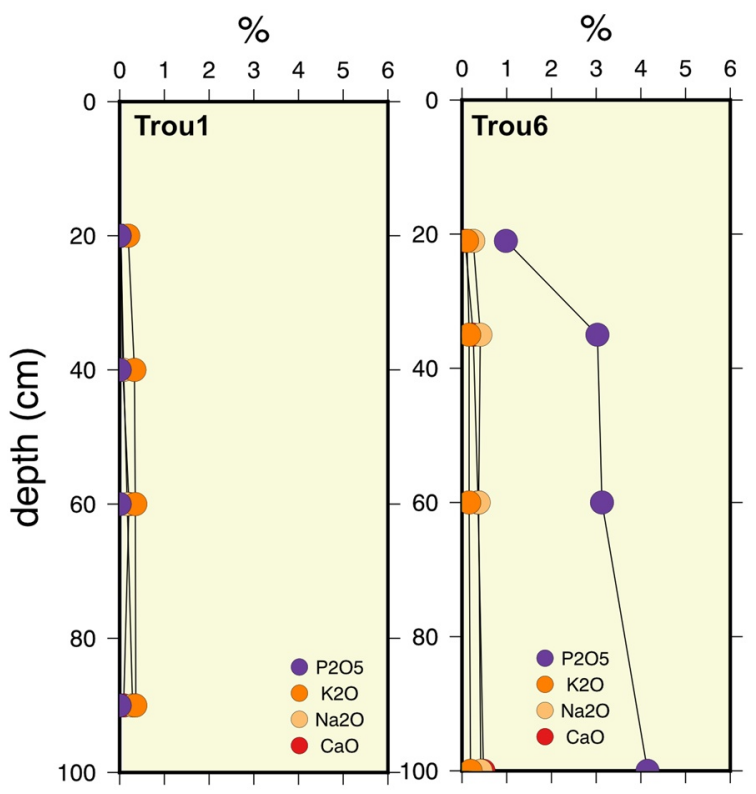

BARREN ZONE

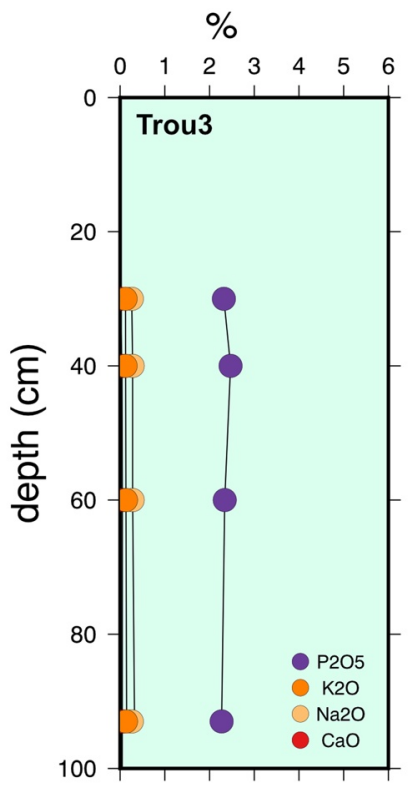

TREE RING

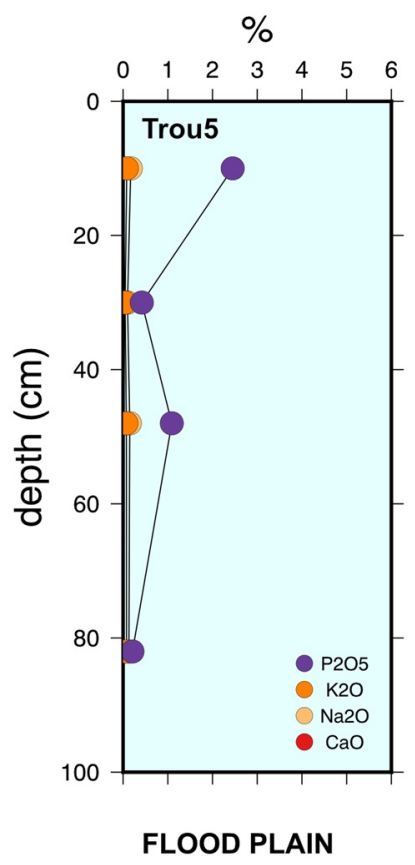

Figure 6. $\mathrm{CaO}, \mathrm{K}_{2} \mathrm{O}, \mathrm{Na}_{2} \mathrm{O}$, and $\mathrm{P}_{2} \mathrm{O}_{5}$ contents in the sediments sampled in the first meter of four boreholes. The location of the boreholes is plotted in Figure 3 . Note the very low content $(<0.5 \%)$ in $\mathrm{CaO}, \mathrm{K}_{2} \mathrm{O}, \mathrm{Na}_{2} \mathrm{O}$. The content in $\mathrm{P}_{2} \mathrm{O}_{5}$ is up to $3 \%$ in the boreholes closest to the free water.

\subsection{Sediment Chemistry}

Simple field observations do not show evaporitic deposits at the surface (Figure 2). To check it, we analyzed the anions $\left(\mathrm{CaO}, \mathrm{K}_{2} \mathrm{O}, \mathrm{Na}_{2} \mathrm{O}, \mathrm{P}_{2} \mathrm{O}_{5}\right)$ of sediments sampled in 4 boreholes (Figure 6). For each borehole, the contents in $\mathrm{CaO}, \mathrm{K}_{2} \mathrm{O}, \mathrm{Na}_{2} \mathrm{O}$ is less than $0.5 \%$ of total content of the sediment, up to $1 \mathrm{~m}$ in depth. No main differences appear between the different boreholes, except for the phosphates. The boreholes Trou6, Trou4, and Trou5 display higher percent in $\mathrm{P}_{2} \mathrm{O}_{5}$ (until 5.2\% in Trou6), while the prevent in Trou1 is less than $0.5 \%$. These boreholes have more connection with the fresh water than the Troul located in the middle part of the barren zone: the Trou 5 is in the flood plain, the Trou 3 in the tree ring, and the Trou6 in the border of barren zone, in a part inundated during the highest floods. Thus, there is no abnormal contents in geochemical content that can be attributed to an evaporitic process.

\section{Toward a New Hydrological Model}

The chemical analysis on groundwater in the barren zone and in the floodplain are very different: a fresh water in the floodplain and a saline water in the barren zone. The REE patterns indicate that the saline water can be derived from fresh water by evapotranspiration. The sediment composition is similar in the flood plain and in the barren zone: therefore, the chemical composition of water cannot result in an equilibrium with sediments. Furthermore, the dynamics of the groundwater table inside the island is decorrelated to the flood cycle and rainfall supply: this strongly suggests the presence of two different, poorly connected to unconnected aquifers: a superficial one in the channel-floodplain system and a deeper one, possibly captive within the island. At least, the geochemical analysis of sediments reveals similar chemical composition both in the flood plain and in the barren zone, not consistent with the presence of evaporitic deposits in the barren zone, as previously described in other islands with percent in $\mathrm{Ca} 0$ higher than $5 \%$ (McCarthy, 2006, 2013; McCarthy et al., 2012).

The compositional transition in between saline water in the barren zone and fresh water in the floodplain is abrupt: it occurs over a maximum distance of $20 \mathrm{~m}$ separating two piezometers, and at the boundary in between the tree ring and the barren zone, within the area covered by bushes. This abrupt horizontal stairshape-like concentration gradient is poorly compatible with a diffusion model in between two such different compartments. A diffusion process should indeed generate a transitional composition over a longer 

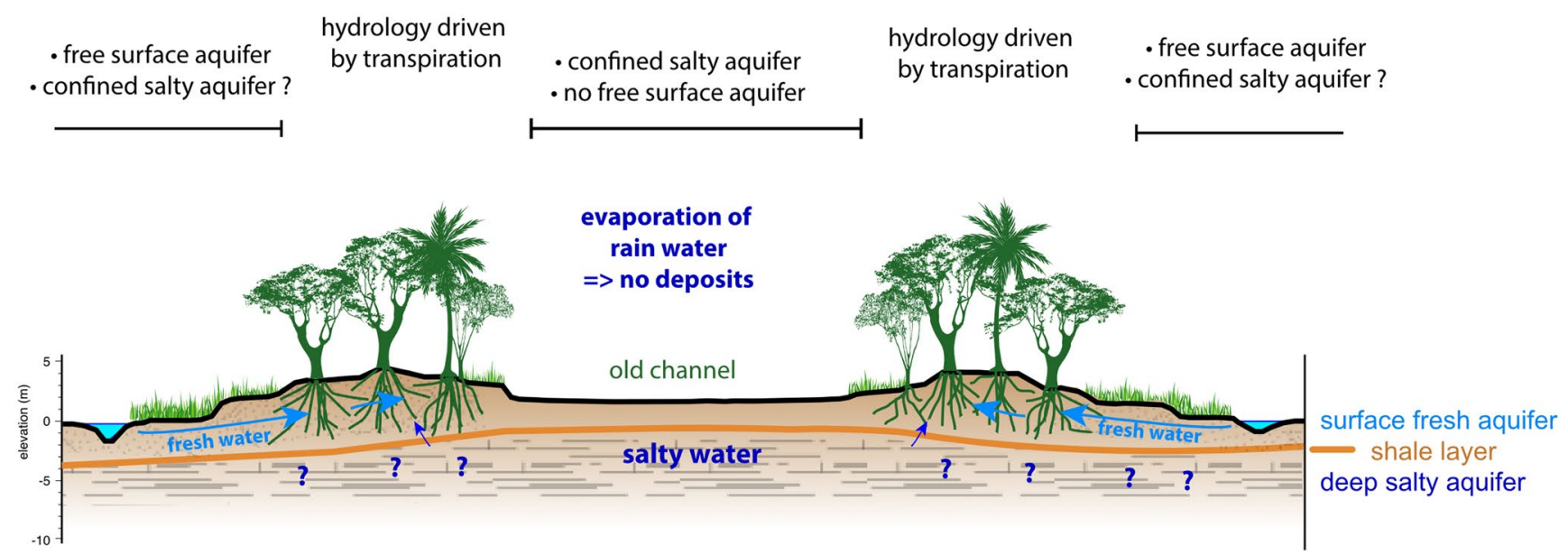

Figure 7. Hydrological structure of Nxagara Island showing the two aquifers: the surface aquifer with fresh water in the floodplain, and the confined aquifer in the barren zone filled with saline water.

distance. Simple evaporation of water coming from the river or floodplain cannot generate the REE pattern observed in the underground water of the barren zone: evaporation could indeed increase the total REE content but would not generate a differential fractioning throughout the REE series. The chemical quality of the water prevents any deep-rooted vegetation from growing and only short grasses can live on the surface, relying on the seasonal rainfall to ensure their metabolic activity.

\subsection{Hydrological Structure}

The local hydrological dynamics and the highly contrasted geochemistry signature of the waters clearly demonstrate that two different and disconnected aquifers occur in and around Nxaraga Island (Figure 7). This new result is inconsistent with the previously suggested model involving lateral water infiltration from the floodplain toward the island aquifer, driven by the pressure gradient during flooding and by evapotranspiration and evaporation during the dry season (Wolski et al., 2006). The geometry and spatial extend of the subsurface saline aquifer remain poorly defined mainly due to the lack of deep logging in the floodplain. Two hypotheses can be put forward: (a) a restricted aquifer localized in the middle part of the island, as previously suggested by other researchers (Bauer-Gottwein et al., 2007; McCarthy, 2006, 2013; McCarthy et al., 2012; Milzow et al., 2009; Ramberg \& Wolski, 2008), or (b) a wide aquifer spreading outside the island and roofing 2-3 $\mathrm{m}$ from the surface, slightly below the bottom of the Boro River channel. However, this first hypothesis is contradicted by the here above presented geochemical data and by the hydrological dynamics. Geophysical studies (Bauer et al., 2006) suggest the occurrence of a saline aquifer at shallow depth below the inner domain of the island, while Meier et al. (2014) advocate for a wider, but deeper zone, linked to ancient paleo-megalake sediments. The late deposits of the paleolake correspond to either carbonate deposits or shales covering a vast zone that forms a nonpermeable layer at a regional scale thereby enabling the confinement of water at depth and isolating it from the surface.

We therefore propose that the hydrological structure of the Nxaraga Island region includes a wide, confined, subsurface, saline aquifer that is overlain in the floodplain by a free aquifer containing fresh water (Figure 7). This new hydrological setup differs from the previously proposed one that was initially developed in a different hydrological context: Thata Island, among other islands located to the east of Chiefs Island, is surrounded by permanent swamps and supports a saline lake in its central part, evaporite deposits at the surface, and a deep saline aquifer revealing horizontally and vertically connected aquifers (Ellery \& McCarthy, 1998; McCarthy, 2006; McCarthy et al., 2012). By contrast, Nxagara Island is submitted to an annual cycle of dry and wet seasons, and the interior part of the island is never flooded. It also displays two juxtaposed aquifers with their own hydrodynamics and water sources. This suggests that more than one type of hydrological structure exists in the Delta (Figure 8), and thereby revealing a spatial variability in the hydrochemistry dynamics of the Delta that remains to be better constrained by a complete survey and mapping. 
western islands

(Nxagara island)

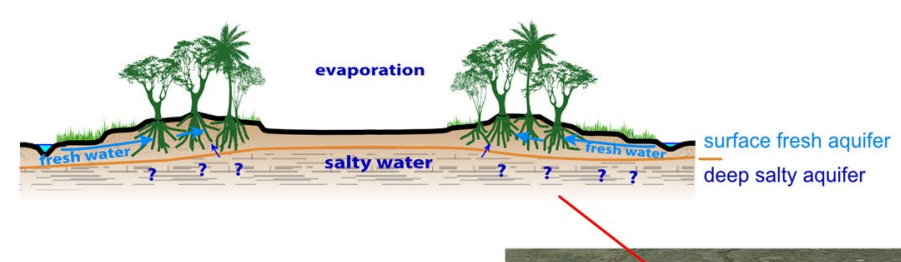

eastern islands

(Thata island)

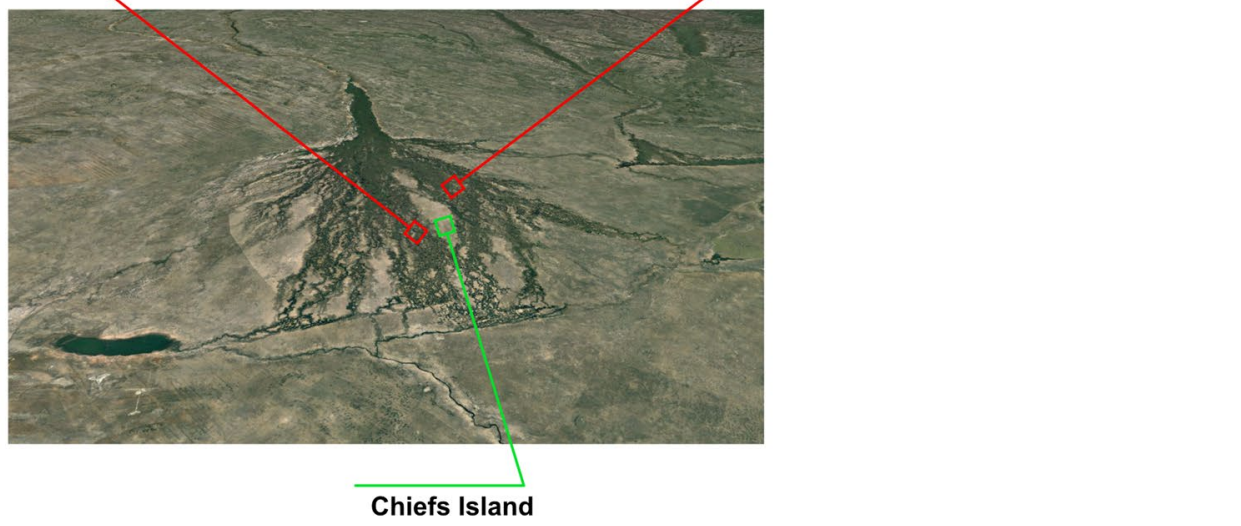

Figure 8. The two types of islands with their own hydrodynamics and water sources: the upper left diagram shows the western island type (Nxaraga) and the upper right diagram shows the eastern island type (Thata). Chiefs Island seems to be a boundary in between these two domains of the Delta (see the location on the 3D view generated in Google Earth).

\subsection{Origin of the Saline Water}

The chemical quality of the water was largely investigated in various places of the Okavango wetland, both in the channels and in the floodplains as well as in boreholes on the islands (Akoko et al., 2013; Bauer-Gottwein et al., 2007; Huntsman-Mapila et al., 2006; Mackay et al., 2011; McCarthy \& Metcalfe, 1990; McCarthy et al., 1998, 2012; Mmualefe \& Torto, 2011; Natalie Mladenov et al., 2014; Ramberg \& Wolski, 2008). They concluded that the variations in the chemical contents are driven by the evaporation of the water flowing from the channels (increased content along the channels and toward the middle part of the island) and by the presence of humic acids in the floodplain that have varying effects on the chemical element contents. However, these authors did not perform any analyses on the REE. Our study is the first to carry out such analyses in the Delta. The model implying a concentration via the evaporation of flood water is largely questioned as it does not account for the peculiar observed REE pattern shapes. Assuming the water source is external to the system, the REE pattern and abnormal chemical composition in certain elements such as $\mathrm{V}, \mathrm{Pb}, \mathrm{As}, \mathrm{Cr}$, $\mathrm{U}$ correspond to high-pH alkaline $\mathrm{CO}_{3}^{2-}$ and $\mathrm{HCO}_{3}^{-}$-rich waters, that is, percolating in carbonate-type rocks such as limestones or dolostones. The basement of the Okavango Delta is made up of Neoproterozoic rocks that include large amounts of dolostones within the Otavi group and the Ghanzi Ridge. This formation hosts a large metallogenic province, including the famous Tsumed mine (Namibia), with the mineralization of $\mathrm{Pb}, \mathrm{Cu}, \mathrm{Zn}, \mathrm{Ge}, \mathrm{Cd}, \mathrm{Ag}, \mathrm{V}$, As, Co, Ge, Ga, Fe, Hg, or Mb. HREE-enriched patterns have also been described in rocks from the Otavi group (Rodler et al., 2016). The oxidation of the poly-metallic deposits began during the Cretaceous as weathering provided oxygenated meteoric waters. This process continued during the Cenozoic when large karst caves were filled with red Kalahari sediments and karst breccias and the carbonated fluids probably helped to form the calcretes that are ubiquitous in northern Namibia and Botswana (Ringrose et al., 2005). This chemically enriched water may have circulated through the Otavi karstic dolostones below the Delta and migrated upward into the fan deposits, possibly contributing to the saline water level imaged by electrical resistance tomography in the Delta (Meier et al., 2014). However, the peculiar chemical signature of the water in the barren zone of Nxaraga Island could have also been acquired in situ from biogeochemical processes given that, in wetland soil or shallow groundwater, REE are often associated with organic matter (Dia et al., 2000). As an example, the reduction of Fe or Mn oxides (generally enriched in REE) by organic matter may result in the precipitation of new HREE-enriched 
Fe-rich phase (Aubert et al., 2001; Davranche et al., 2015). Indeed, the DOC and DIC values increase in the barren zone, indicating a much higher amount of $\mathrm{C}$ there than in the water from the floodplain and river. Similarly, organic matter may also concentrate other trace elements such as U or V (Reijonen et al., 2016), especially at high $\mathrm{pH}$ values. The origin of the organic matter at depth and its comparatively low amount in the surficial deposits in the Nxaraga Island region (except for roughly $15-20 \mathrm{~cm}$ of organic-rich sand at the surface, the sediment seems devoid of organic remnants) is still unknown.

\section{Conclusions}

This work points out a new type of hydrodynamic structure for islands in the southwestern region of the Okavango Delta. This structure is characterized by two disconnected aquifers: a deep saline one possibly extending beyond the interior part of the islands, and a surface fresh-water aquifer that is seasonally refilled by annual flooding and rainfall. This type of hydrological structure differs from the single aquifer, density-driven convective cell previously proposed for Thata island. The islands displaying these two different hydrological structures are distributed on both sides of the large central island (Chiefs Island) showing that the hydrodynamics of the Delta is not homogeneous at large scale. A multidisciplinary study performed at the large scale-including water and sediment geochemical analyses-is thus imperative to better constrain the driving processes of the dynamics of this fragile environment exposed to increasing climate and anthropic pressures. At the very least, considering the highly saline nature of this underground water, it is fundamental to understand its origin as well as the hydrological structure at the scale of the Delta given that this region constitutes such a sensitive ecosystem where any changes (climatic, anthropogenic, or tectonic) could modify the water quality, impacting both the biodiversity and human activities.

\section{Data Availability Statement}

The data are available on the OpenScienceFramework site (https://osf.io/k28pf).

\begin{abstract}
Acknowledgments
This work was funded both by the University of Rennes 1 and by the CNRS/ INSU (TELLUS-Rift and International Emerging Actions program). It is part of a collaboration agreement in between the Okavango Research Institute (University of Botswana) and the University of Rennes 1, and is integrated in the GRD CNRS-INSU Rift research group. The authors would like to thank the technical staff of the ORI for their help in the field. The authors warmly thank S. Lagneau for his inexhaustible knowledge which fueled many interesting and fruitful discussions and P. Petitjean for analyzing the anion, DOC, and DIC concentrations.
\end{abstract}

\section{References}

Ahmed, M., Sultan, M., Wahr, J., \& Yan, E. (2014). The use of GRACE data to monitor natural and anthropogenic induced variations in water availability across Africa. Earth-Science Reviews, 136, 289-300.

Akoko, E., Atekwana, E. A., Cruse, A. M., Molwalefhe, L., \& Masamba, W. R. L. (2013). River-wetland interaction and carbon cycling in a semi-arid riverine system: The Okavango Delta, Botswana. Biogeochemistry, 114(1), 359-380. https://doi.org/10.1007/s10533-012-9817-x

Andersson, L., Gumbricht, T., Hughes, D., Kniveton, D., Ringrose, S., Savenije, H., et al. (2003). Water flow dynamics in the Okavango River Basin and Delta-A prerequisite for the ecosystems of the Delta. Physics and Chemistry of the Earth, Parts A/B/C, 28(20-27), 1165-1172.

Atekwana, E. A., Molwalefhe, L., Kgaodi, O., \& Cruse, A. M. (2016). Effect of evapotranspiration on dissolved inorganic carbon and stable carbon isotopic evolution in rivers in semi-arid climates: The Okavango Delta in North West Botswana. Journal of Hydrology: Regional Studies, 7, 1-13. https://doi.org/10.1016/j.ejrh.2016.05.003

Aubert, D., Stille, P., \& Probst, A. (2001). REE fractionation during granite weathering and removal by waters and suspended loads: Sr and Nd isotopic evidence. Geochimica et Cosmochimica Acta, 65(3), 387-406. https://doi.org/10.1016/S0016-7037(00)00546-9

Barboni, D., Ashley, G. M., Bourel, B., Arráiz, H., \& Mazur, J.-C. (2019). Springs, palm groves, and the record of early hominins in Africa. Review of Palaeobotany and Palynology, 266, 23-41. https://doi.org/10.1016/j.revpalbo.2019.03.004

Bauer-Gottwein, P., Langer, T., Prommer, H., Wolski, P., \& Kinzelbach, W. (2007). Okavango Delta Islands: Interaction between density-driven flow and geochemical reactions under evapo-concentration. Journal of Hydrology, 335(3), 389-405. https://doi.org/10.1016/j. jhydrol.2006.12.010

Bauer, P., Supper, R., Zimmermann, S., \& Kinzelbach, W. (2006). Geoelectrical imaging of groundwater salinization in the Okavango Delta, Botswana. Journal of Applied Geophysics, 60(2), 126-141. https://doi.org/10.1016/j.jappgeo.2006.01.003

Bauer, P., Thabeng, G., Stauffer, F., \& Kinzelbach, W. (2004). Estimation of the evapotranspiration rate from diurnal groundwater level fluctuations in the Okavango Delta, Botswana. Journal of Hydrology, 288(3), 344-355. https://doi.org/10.1016/j.jhydrol.2003.10.011

Bayon, G., Toucanne, S., Skonieczny, C., André, L., Bermell, S., Cheron, S., et al. (2015). Rare earth elements and neodymium isotopes in world river sediments revisited. Geochimica et Cosmochimica Acta, 170, 17-38. https://doi.org/10.1016/j.gca.2015.08.001

Cawley, K. M., Wolski, P., Mladenov, N., \& Jaffé, R. (2012). Dissolved organic matter biogeochemistry along a transect of the Okavango Delta, Botswana. Wetlands, 32(3), 475-486. https://doi.org/10.1007/s13157-012-0281-0

Davranche, M., Gruau, G., Dia, A., Marsac, R., Pédrot, M., \& Pourret, O. (2015). Biogeochemical factors affecting rare earth element distribution in shallow wetland groundwater. Aquatic Geochemistry, 21(2), 197-215. https://doi.org/10.1007/s10498-014-9247-6

Dia, A., Gruau, G., Olivié-Lauquet, G., Riou, C., Molénat, J., \& Curmi, P. (2000). The distribution of rare earth elements in groundwaters: Assessing the role of source-rock composition, redox changes and colloidal particles. Geochimica et Cosmochimica Acta, 64(24), 4131-4151. https://doi.org/10.1016/S0016-7037(00)00494-4

Ellery, W. N., \& McCarthy, T. S. (1994). Principles for the suitainable utilization of the Okavango Delta ecosystem, Botswana. Biological Conservation, 70, 159-168. 
Ellery, W. N., \& McCarthy, T. S. (1998). Environmental change over two decades since dredging and excavation of the lower Boro River, Okavango Delta, Botswan. Journal of Biogeography, 25(2), 361-378. https://doi-org.insu.bib.cnrs.fr/10.1046/j.1365-2699.1998.252168.x

Frondini, F., Dragoni, W., Morgantini, N., Donnini, M., Cardellini, C., Caliro, S., et al. (2019). An Endorheic Lake in a changing climate: Geochemical investigations at Lake Trasimeno (Italy). Water, 11(7), 1319. https://doi.org/10.3390/w11071319

Gumbricht, T., McCarthy, T. S., \& Merry, C. L. (2001). The topography of the Okavango Delta, Botswana, and its tectonic and sedimentological implications. South African Journal of Geology, 104, 243-264.

Gumbricht, T., Wolski, P., Frostc, P., \& McCarthya, T. S. (2004). Forecasting the spatial extent of the annual flood in the Okavango delta, Botswana. Journal of Hydrology, 290, 178-191.

Habeck-Fardy, A., \& Nanson, G. C. (2014). Environmental character and history of the Lake Eyre Basin, one seventh of the Australian continent. Earth-Science Reviews, 132, 39-66. https://doi.org/10.1016/j.earscirev.2014.02.003

Hammer, U. T. (1986). Saline lake ecosystems of the world. Springer Science \& Business Media.

Huntsman-Mapila, P., Mapila, T., Letshwenyo, M., Wolski, P., \& Hemond, C. (2006). Characterization of arsenic occurrence in the water and sediments of the Okavango Delta, NW Botswana. Applied Geochemistry, 21(8), 1376-1391.

Huntsman-Mapila, P., Ringrose, S., Mackay, A. W., Downey, W. S., Modisi, M., Coetzee, S. H., et al. (2006). Use of the geochemical and biological sedimentary record in establishing palaeo-environments and climate change in the Lake Ngami basin, NW Botswana. Quaternary International, 148(1), 51-64.

Kenabatho, P. K., Parida, B. P., \& Moalafhi, D. B. (2012). The value of large-scale climate variables in climate change assessment: The case of Botswana's rainfall. Physics and Chemistry of the Earth, Parts A/B/C, 50-52, 64-71. https://doi.org/10.1016/j.pce.2012.08.006

Kinabo, B. D., Atekwana, E. A., Hogan, J. P., Modisi, M. P., Wheaton, D. D., \& Kampunzu, A. B. (2007). Early structural development of the Okavango rift zone, NW Botswana. Journal of African Earth Sciences, 48, 125-136.

Mackay, A. W., Davidson, T., Wolski, P., Mazebedi, R., Masamba, W. R. L., Huntsman-Mapila, P., \& Todd, M. (2011). Spatial and seasonal variability in surface water chemistry in the Okavango Delta, Botswana: A multivariate approach. Wetlands, 31(5), 815. https://doi. org/10.1007/s13157-011-0196-1

Mahamat Nour, A., Vallet-Coulomb, C., Bouchez, C., Ginot, P., Doumnang, J. C., Sylvestre, F., \& Deschamps, P. (2020). Geochemistry of the Lake Chad tributaries under strongly varying hydro-climatic conditions. Aquatic Geochemistry, 26(1), 3-29. https://doi.org/10.1007/ s10498-019-09363-w

Markofsky, S., Ninfo, A., Balbo, A., Conesa, F. C., \& Madella, M. (2017). An investigation of local scale human/landscape dynamics in the endorheic alluvial fan of the Murghab River, Turkmenistan. Quaternary International, 437, 1-19. https://doi.org/10.1016/j. quaint.2016.01.006

McCarthy, T. S. (1993). The great inland deltas of Africa. Journal of African Earth Sciences, 17(3), 275-291. https://doi. org/10.1016/0899-5362(93)90073-Y

McCarthy, T. S. (2006). Groundwater in the wetlands of the Okavango Delta, Botswana, and its contribution to the structure and function of the ecosystem. Journal of Hydrology, 320(3), 264-282. https://doi.org/10.1016/j.jhydrol.2005.07.045

McCarthy, T. S. (2013). The Okvango Delta and Its place in the geomorphological evolution of Southern Africa. South African Journal of Geology, 116(1), 1-54. https://doi.org/10.2113/gssajg.116.1.1

McCarthy, T. S., Ellery, W. N., \& Dangerfield, J. M. (1998). The role of biota in the initiation and growth of islands on the floodplain of the Okavango alluvial fan, Botswana. Earth Surface Processes and Landforms, 23(4), 291-316. https://doi.org/10.1002/ (SICI)1096-9837(199804)23:4<291::AID-ESP844>3.0.CO;2-A

McCarthy, T. S., Ellery, W. N., Rogers, K. H., Cairncross, B., \& Ellery, K. (1986). The roles of sedimentation and plant growth in the changing flow patterns in the Okavango Delta, Botswana. Suid-Afrikaanse Tydskrif Wetenskap, 82, 2-7.

McCarthy, T. S., Humphries, M. S., Mahomed, I., Le Roux, P., \& Verhagen, B. T. (2012). Island forming processes in the Okavango Delta, Botswana. Geomorphology, 179, 249-257. https://doi.org/10.1016/j.geomorph.2012.08.016

McCarthy, T. S., \& Metcalfe, J. (1990). Chemical sedimentation in the semi-arid environment of the Okavango Delta, Botswana. Chemical Geology, 89(1), 157-178. https://doi.org/10.1016/0009-2541(90)90065-F

Meier, P., Kalscheuer, T., Podgorski, J. E., Kgotlhang, L., Green, A. G., Greenhalgh, S., et al. (2014). Hydrogeophysical investigations in the western and north-central Okavango Delta (Botswana) based on helicopter and ground-based transient electromagnetic data and electrical resistance tomographyERT and TEM in the Okavango Delta. Geophysics, 79(5), B201-B211. https://doi.org/10.1190/geo2014-0001.1

Milzow, C., Kgotlhang, L., Bauer-Gottwein, P., Meier, P., \& Kinzelbach, W. (2009). Regional review: The hydrology of the Okavango Delta, Botswana-Processes, data and modelling. Hydrogeology Journal, 17(6), 1297-1328. https://doi.org/10.1007/s10040-009-0436-0

Mladenov, N., McKnight, D. M., Wolski, P., \& Murray-Hudson, M. (2007). Simulation of DOM fluxes in a seasonal floodplain of the Okavango Delta, Botswana. Ecological Modelling, 205(1), 181-195. https://doi.org/10.1016/j.ecolmodel.2007.02.015

Mladenov, N., Wolski, P., Hettiarachchi, G. M., Murray-Hudson, M., Enriquez, H., Damaraju, S., et al. (2014). Abiotic and biotic factors influencing the mobility of arsenic in groundwater of a through-flow island in the Okavango Delta, Botswana. Journal of Hydrology, 518, 326-341. https://doi.org/10.1016/j.jhydrol.2013.09.026

Mmualefe, L. C., \& Torto, N. (2011). Water quality in the Okavango Delta. Water SA, 37(3). https://doi.org/10.4314/wsa.v37i3.68492

Moore, A. E., Cotterill, F. P. D., woody), \& Eckardt, F. D. (2012). The evolution and ages of Makgadikgadi palaeo-lakes: Consilient evidence from Kalahari drainage evolution south-central Africa. South African Journal of Geology, 115(3), 385-413. https://doi.org/10.2113/ gssajg.115.3.385

Moore, A. E., \& Larkin, P. A. (2001). Drainage evolution in south-central Africa since the breakup of Gondwana. South African Journal of Geology, 104(1), 47-68. https://doi.org/10.2113/104.1.47

Nance, W. B., \& Taylor, S. R. (1976). Rare earth element patterns and crustal evolution-I. Australian post-Archean sedimentary rocks. Geochimica et Cosmochimica Acta, 40(12), 1539-1551. https://doi.org/10.1016/0016-7037(76)90093-4

Pastier, A.-M., Dauteuil, O., Murray-Hudson, M., Moreau, F., Walpersdorf, A., \& Makati, K. (2017). Is the Okavango Delta the terminus of the East African Rift System? Towards a new geodynamic model: Geodetic study and geophysical review. Tectonophysics, 712-713(Supplement C), 469-481. https://doi.org/10.1016/j.tecto.2017.05.035

Ramberg, L., \& Wolski, P. (2008). Growing islands and sinking solutes: Processes maintaining the endorheic Okavango Delta as a freshwater system. Plant Ecology, 196(2), 215-231. https://doi.org/10.1007/s11258-007-9346-1

Ramillien, G., Bouhours, S., Lombard, A., Cazenave, A., Flechtner, F., \& Schmidt, R. (2008). Land water storage contribution to sea level from GRACE geoid data over 2003-2006. Global and Planetary Change, 60, 381-392.

Reijonen, I., Metzler, M., \& Hartikainen, H. (2016). Impact of soil pH and organic matter on the chemical bioavailability of vanadium species: The underlying basis for risk assessment. Environmental Pollution, 210, 371-379. https://doi.org/10.1016/j.envpol.2015.12.046 
Ringrose, S., Huntsman-Mapila, P., Kampunzu, A. B., Downey, W., Coetzee, S., Vink, B., et al. (2005). Sedimentological and geochemical evidence for palaeo-environmental change in the Makgadikgadi subbasin, in relation to the MOZ rift depression, Botswana. Palaeogeography, Palaeoclimatology, Palaeoecology, 217, 265-287.

Ringrose, S., Vanderpost, C., Matheson, W., Wolski, P., Huntsman-Mapila, P., Murray-Hudson, M., \& Jellema, A. (2007). Indicators of desiccation-driven change in the distal Okavango Delta, Botswana. Journal of Arid Environments, 68(1), 88-112. https://doi.org/10.1016/j. jaridenv.2006.03.030

Rodler, A. S., Frei, R., Gaucher, C., \& Germs, G. J. B. (2016). Chromium isotope, REE and redox-sensitive trace element chemostratigraphy across the late Neoproterozoic Ghaub glaciation, Otavi Group, Namibia. Precambrian Research, 286, 234-249. https://doi.org/10.1016/j. precamres.2016.10.007

Tsheboeng, G., Bonyongo, M., \& Murray-Hudson, M. (2014). Flood variation and soil nutrient content in floodplain vegetation communities in the Okavango Delta. South African Journal of Science, 110(3/4), 1-5. https://doi.org/10.1590/sajs.2014/20130168

Tweed, S., Leblanc, M., Cartwright, I., Favreau, G., \& Leduc, C. (2011). Arid zone groundwater recharge and salinisation processes; an example from the Lake Eyre Basin, Australia. Journal of Hydrology, 408(3), 257-275. https://doi.org/10.1016/j.jhydrol.2011.08.008

Wang, J., Song, C., Reager, J. T., Yao, F., Famiglietti, J. S., Sheng, Y., et al. (2018). Recent global decline in endorheic basin water storages. Nature Geoscience, 11(12), 926-932. https://doi.org/10.1038/s41561-018-0265-7

Wolski, P., \& Murray-Hudson, M. (2008). An investigation of permanent and transient changes in flood distribution and outflows in the Okavango Delta, Botswana. Physics and Chemistry of the Earth, 33, 157-164.

Wolski, P., Savenije, H. H. G., Murray-Hudson, M., \& Gumbricht, T. (2006). Modelling of the flooding in the Okavango Delta, Botswana, using a hybrid reservoir-GIS model. Journal of Hydrology Water Resources in Regional Development: The Okavango River, 331(1-2), 58-72.

Wolski, P., Todd, M. C., Murray-Hudson, M. A., \& Tadross, M. (2012). Multi-decadal oscillations in the hydro-climate of the Okavango River system during the past and under a changing climate. Journal of Hydrology, 475, 294-305. https://doi.org/10.1016/j.jhydrol.2012.10.018 Yapiyev, V., Sagintayev, Z., Inglezakis, V. J., Samarkhanov, K., \& Verhoef, A. (2017). Essentials of endorheic and lakes: A review in the context of current and future water resource management and mitigation activities in Central Asia. Water, 9, 798. 